\title{
Identification of a human lactoferrin-binding protein in Staphylococcus aureus
}

\author{
A.S. NAIDU, M. ANDERSSON and A. FORSGREN
}

Department of Medical Microbiology, University of Lund, Malmö General Hospital, S-21401 Malmö, Sweden

\begin{abstract}
Summary. Human lactoferrin (HLf) is an iron-binding protein with antimicrobial activity that is present in high concentrations in milk and various exocrine secretions. HLf is also an acute-phase protein secreted by polymorphonuclear leucocytes, and its binding to a large number of clinical isolates of Staphylococcus aureus has been described recently from our laboratory. We have now characterised the HLf-staphylococcal interaction in $S$. aureus strain MAS-89. The binding of ${ }^{125}$ I-HLf to strain MAS-89 reached saturation in $<90 \mathrm{~min}$ and was maximal between $\mathrm{pH} 4$ and 9 . Unlabelled HLf displaced ${ }^{125} \mathrm{I}$-HLf binding. Various plasma and subepithelial matrix proteins, such as IgG, fibrinogen, fibronectin, collagen and laminin, which are known to interact specifically with $S$. aureus, did not interfere with HLf binding. A Scatchard plot was non-linear; this implied a low affinity $\left(1.55 \times 10^{7} \mathrm{~L} / \mathrm{mol}\right)$ and a high affinity $\left(2.70 \times 10^{8} \mathrm{~L} / \mathrm{mol}\right)$ binding mechanism. We estimated that there were $c .5700$ HLf binding sites/cell. The staphylococcal HLf-binding protein (HLf-BP) was partially susceptible to proteolytic enzymes or periodate treatment and was resistant to glycosidases. An active HLf-BP with an apparent $\mathrm{M}_{\mathrm{r}}$ of $c .450 \mathrm{Kda}$ was isolated from strain MAS-89 cell lysate by ion-exchange chromatography on Q-sepharose. In SDS-PAGE, the reduced HLf$\mathrm{BP}$ was resolved into two components of 67 and $62 \mathrm{Kda}$. The two components demonstrated a positive reaction with HLf-HRPO in a Western blot. These data establish that there is a specific receptor for HLf in $S$. aureus.
\end{abstract}

\section{Introduction}

Human lactoferrin (HLf) is an iron-binding protein with anti-microbial activity that is present in milk, leucocytes and various exocrine secretions. ${ }^{1,2}$ Human plasma contains $c .1 \mu \mathrm{g}$ of $\mathrm{HLf} / \mathrm{ml}$, with a turnover rate of $5.7 \%$ per day, processed mainly by the liver. ${ }^{3}$ HLf is a glycoprotein of $c .80 \mathrm{Kda}$ and is composed of a single polypeptide chain with two heterogeneous glycans attached through $\mathrm{N}$-glycosidic linkages. ${ }^{4,5}$ HLf has a capacity to bind reversibly two $\mathrm{Fe}^{3+}$ ions with high affinity $\left(\mathrm{K}_{\mathrm{a}}=10^{20} \mathrm{~L} / \mathrm{mol}\right)$, in co-operation with two $\mathrm{HCO}_{3}{ }^{-}$ions. ${ }^{6,7}$

The involvement of HLf in various physiological pathways has been suggested. ${ }^{8}$ It regulates myelopoiesis and thereby antibody production by causing feed-back inhibition of granulocyte-monocyte colony stimulating factor. ${ }^{9,10}$ HLf also stimulates the cidal properties of phagocytes and participates in $\mathrm{H}_{2} \mathrm{O}_{2}$ dependent and -independent bacterial killing. ${ }^{11,12}$

The antimicrobial property of HLf has been attributed mainly to its iron-scavenging capacity. A bacteriostatic, a bactericidal, and an opsonic effect for HLf has been suggested. ${ }^{12-14}$ The antimicrobial activity increases when HLf adsorbs to bacterial surfaces. ${ }^{15}$ Moreover, interaction of HLf with gramnegative bacteria has been shown to cause permeability alterations in the outer membrane and release of lipopolysaccharide. ${ }^{16}$

Other studies have revealed a specific receptormediated interaction of HLf with Neisseria meningitidis, $N$. gonorrhoeae, Haemophilus influenzae, Treponema pallidum and Trichomonas vaginalis. ${ }^{17-21}$ These studies have suggested that HLf receptors may play a role in bacterial iron acquisition. Thus, the significance of HLf-bacterial interaction has been attributed to both host defence mechanisms and bacterial virulence.

Recently, we have demonstrated the binding of HLf to various clinical isolates of $S$. aureus. ${ }^{22}$ Furthermore, we have also reported the interaction of bovine Lf (BLf) with $S$. aureus and coagulase-negative staphylococci associated with bovine mastitis. ${ }^{23,24}$ We have now examined the presence of a specific HLf-binding protein (HLf-BP) in $S$. aureus and have characterised the HLf-staphylococcal interaction in $S$. aureus strain MAS-89.

Received 11 Feb. 1991 ; revised version accepted 9 May 1991. 


\section{Materials and methods}

\section{Chemicals}

HLf (lot 63541) purified from milk was purchased from US Biochemicals Corp., Cleveland, OH, USA. BLf purified from whey was kindly provided by $\mathrm{Dr} \mathrm{H}$. Burling, Research Division, Swedish Dairies Association, Lund, Sweden. Both Lf preparations were homogeneous when tested in ion-exchange (Mono-Q column, Pharmacia AB, Uppsala, Sweden) and in molecular-sieve (TSK G4000 SW, LKB Produkter AB, Bromma, Sweden) high-performance liquid chromatography. Fibronectin was purified from human plasma by the method of Veunto and Vaheri, ${ }^{25}$ and was provided by $\mathrm{Dr}$ J. Erdei. Laminin (from basement membrane of the Engelbreth-Holm-Swarm transplantable tumour) was purchased from Collaborative Research, Inc., Bedford, MA, USA. Vitrogen- $100^{\mathrm{TM}}$ (containing type I $95 \%$ and type III $5 \%$ collagens) was purchased from Collagen Corporation Inc., Palo Alto, CA, USA. Human immunoglobulin-G was obtained from Kabi Vitrum, Stockholm, Sweden.

The following substances were obtained from Sigma: Chemicals - phenylmethylsulphonyl fluoride, sodium-p-periodate, diamino-benzidine; Proteinsfibrinogen (from human plasma), transferrin (from human serum), fetuin (from fetal calf serum), trypsin inhibitor (from soy bean) and human serum albumin; Sugars-glucose, mannose, fucose, sorbitol, ribose, sialic acid type-VIII (from sheep submaxillary glands), $\mathrm{N}$-acetyl-D-galactosamine, and $\mathrm{N}$-acetyl-D-glucosamine; Enzymes-trypsin (type-XIIS), pepsin (from porcine stomach mucosa, proteinase $\mathbf{K}$ (type-XIS, from Tritirachium album), $\beta$-glucosidase (from almonds), $\beta$-galactosidase (from Escherichia coli), $\alpha$-1 fucosidase, neuraminidase, deoxyribonuclease II (from bovine spleen), ribonuclease A (from bovine pancreas), peroxidase (from horse-radish) and lysostaphin. All chemicals used in the preparation of buffer solutions were of analytical grade.

\section{Bacteria}

In a previous study, ${ }^{22}$ we examined $489 S$. aureus isolates (from various clinical conditions in man) and found $417(85 \cdot 3 \%)$ strains that bound ${ }^{125}$ I-HLf. From this collection, a high-HLf-binding $S$. aureus strain, MAS-89, was selected for characterisation in the present study. Strain MAS-89 was associated with toxic shock syndrome, and has been extensively characterised for various biochemical properties in earlier studies. ${ }^{26-28}$ For binding experiments, bacteria were grown on blood agar at $37^{\circ} \mathrm{C}$ for $24 \mathrm{~h}$. Cells were harvested, washed and resuspended in phosphatebuffered saline (PBS), pH 7.2, to a density of $10^{10}$ bacteria/ml (standardised spectrophotometrically at $540 \mathrm{~nm}$ ).

\section{${ }^{125}$ I-HLf binding assay}

HLf was labelled by a modified chloramine-T method with $\mathrm{Na}^{125} \mathrm{I}$ (specific activity $629 \mathrm{GBq} / \mathrm{mg}$; DuPont Scandinavia AB, Stockholm, Sweden) by means of Iodobeads (Pierce Chemicals Co., Rockford, IL, USA). The ${ }^{125}$ I-HLf preparation was homogeneous in autoradiography after SDS-PAGE. The binding assay was performed as described previously. ${ }^{22-24}$ Briefly, $10^{9}$ bacteria (in $0.1 \mathrm{ml}$ of PBS) were mixed with $0.1 \mathrm{ml}$ of ${ }^{125} \mathrm{I}$-HLf solution [c. $8 \mathrm{ng}$, corresponding to a radioactivity of $\left.(2 \cdot 5-3.0) \times 10^{4} \mathrm{cpm}\right]$ and incubated for $1 \mathrm{~h}$ at room temperature. After adding $2 \mathrm{ml}$ of ice-cold PBS (containing Tween $200 \cdot 1 \%$ ), tubes were centrifuged at $9500 \mathrm{~g}$ for $15 \mathrm{~min}$ and the supernate was aspirated. Radio-activity bound to the bacterial pellet was measured in a $\gamma$-counter (LKB Wallac Clinigamma 1272, Turku, Finland). Background radio-activity from incubation mixtures without bacteria was $2.5 \%$, and the non-specific ${ }^{125} \mathrm{I}-\mathrm{HLf}$ binding to $S$. aureus (in the presence of 100 -fold excess of unlabelled HLf) was $c .7 \cdot 5 \%$. Therefore, a binding value of $<10 \%$ was considered to be a negative result. Samples were tested in triplicate and each experiment was repeated at least twice unless otherwise stated.

\section{Enzymatic treatment of bacteria}

A suspension of $S$. aureus strain MAS-89 $\left(10^{9}\right.$ bacteria/0.1 ml) harvested from blood agar was treated with proteases or glycosidases (final volume, $0.2 \mathrm{ml}$ ). Trypsin (25 000 units $/ \mathrm{ml}$ ) digestion was performed in $0 \cdot 15 \mathrm{~m}$ PBS, $\mathrm{pH} 7 \cdot 4$, and the reaction was blocked with soybean trypsin inhibitor. Pepsin (10 000 units/ $\mathrm{ml}$ ) treatment was performed in $100 \mathrm{~mm}$ sodium acetate buffer, $\mathrm{pH} 4 \cdot 5$, and was stopped by increasing the $\mathrm{pH}$ of the reaction mixture to $7 \cdot 4$. Proteinase $\mathrm{K}$ (100 units $/ \mathrm{ml})$ digestion was performed in $40 \mathrm{~mm}$ potassium phosphate buffer, $\mathrm{pH} 7 \cdot 5$, and the reaction was inhibited by adding $0.5 \mathrm{M}$ phenylmethylsulphonylfluoride. Glycosidase treatment with neuraminidase (10 units $/ \mathrm{ml}), \beta$-galactosidase (100 units $/ \mathrm{ml})$ of $\alpha-1$ fucosidase $(0.5$ units $/ \mathrm{ml})$ was performed in $30 \mathrm{~mm}$ Tris- $\mathrm{HCl}$ buffer, $\mathrm{pH} 7 \cdot 3$. After enzymatic treatment for $1 \mathrm{~h}$, the bacteria were thoroughly washed and resuspended in PBS. Untreated cells suspended in appropriate buffers were tested as controls.

\section{Heat or periodate treatment of bacteria}

A $1-\mathrm{ml}$ volume of bacterial suspension $\left(10^{10}\right.$ cells/ $\mathrm{ml}$ ) was heated at $80^{\circ} \mathrm{C}$ or $100^{\circ} \mathrm{C}$ for $1 \mathrm{~h}$, with gentle shaking in a water bath. For periodate treatment, $1 \mathrm{ml}$ of bacterial suspension ( $10^{11}$ cells) was mixed with $5 \mathrm{mg}$ of sodium periodate. The mixture was protected from light and kept at $4^{\circ} \mathrm{C}$ with gentle agitation. After incubation for $24 \mathrm{~h}$, the mixture was centrifuged at $500 \mathrm{rpm}$ for $5 \mathrm{~min}$ (sodium periodate crystals were sedimented) and the bacteria from the supernate were carefully collected. Any excess of sodium periodate was removed by dialysis with PBS at $4^{\circ} \mathrm{C}$ for $24 \mathrm{~h}$. The 
density of the sodium periodate-free cell suspension was adjusted to $10^{10} \mathrm{cells} / \mathrm{ml}$.

\section{Isolation of staphylococcal HLf-binding protein (HLf-BP)}

$S$. aureus strain MAS-89 cell surface components were extracted by the technique of Rydén et al. ${ }^{29}$ Briefly, $20 \mathrm{~g}$ (wet weight) of bacteria were suspended in $200 \mathrm{ml}$ of $50 \mathrm{mM}$ Tris- $\mathrm{HCl}, \mathrm{pH} 7.5$ (Tris-buffer), containing $0.145 \mathrm{M} \mathrm{NaCl}, 2 \mathrm{mg}$ of lysostaphin, $2 \mathrm{mg}$ of DNAase and $2 \mathrm{mg}$ of RNAase. After incubation with constant shaking $(200 \mathrm{rpm})$ at $37^{\circ} \mathrm{C}$ for $2 \mathrm{~h}$, the reaction mixture was centrifuged ( $18000 \mathrm{~g}$ for $30 \mathrm{~min}$ ) and the supernate (now termed "lysate") was collected. The presence of functionally active HLf-BP in the lysate was detected in an ${ }^{125} \mathrm{I}$-HLf binding inhibition assay with strain MAS- 89 whole cells. Lysate $(50 \mathrm{ml})$ was applied to a column $(25 \times 2.5 \mathrm{~cm})$ of Q-Sepharose (Pharmacia) equilibrated with Tris-buffer. After a thorough wash with Tris-buffer, the column was eluted with a 1250 -ml salt gradient $(0-1.0 \mathrm{M} \mathrm{NaCl}$ in Trisbuffer) at a flow rate of $48 \mathrm{ml} / \mathrm{h}$ and fractions $(10 \mathrm{ml})$ were collected. All buffers and solutions used in the chromatography contained $1 \mathrm{mM}$ phenylmethylsulphonyl fluoride. Duplicate samples $(0.2 \mathrm{ml})$ from each fraction were incubated overnight at $4^{\circ} \mathrm{C}$, in a 96-well microtitration plate (Nunc, Roskilde, Denmark). Free sites in the well were blocked with ovalbumin $2 \%$. Horse-radish peroxidase (HLf-HRPO) was prepared according to the method of Nakamura et al. ${ }^{30}$ and used as a probe for detecting the HLf-BP activity. Enzyme-linked ligand-binding assay was performed essentially as described for a standard ELISA. ${ }^{31} O$ phenylenediamine (Sigma) prepared in $34 \mathrm{mM}$ citrate buffer, $\mathrm{pH} 5 \cdot 4$, containing $\mathrm{H}_{2} \mathrm{O}_{2} 0.55 \%$ was used as the enzyme substrate. Enzyme hydrolysis was terminated with $4 \mathrm{~N}$ sulphuric acid $(25 \mu \mathrm{l})$ and the colour development was measured at $450 \mathrm{~nm}$ in a Titertek Multiscan. Fraction(s) that gave a positive reaction were tested for blocking of ${ }^{125} \mathrm{I}$-HLf binding to strain MAS- 89 whole cells. The active fraction was further analysed for homogeneity, on a Mono-Q (Pharmacia) column by high-performance liquid chromatography with 200- $\mu$ l samples); the equilibration buffer was $0.2 \mathrm{M}$ Tris-Bis, $\mathrm{pH} 2$; the elution-equilibration buffer had a gradient of $0 \cdot 01-4 \cdot 0 \mathrm{M} \mathrm{NaCl}$.

\section{Gel electrophoresis}

The molecular weight determination of the isolated HLf-BP was determined in SDS-PAGE according to the method of Studier $^{32}$ with two electrophoretic conditions. (i) The running gel was prepared with acrylamide $5 \%$; non-reduced samples were applied to lanes; gels were developed with silver stain after electrophoresis; and cross-linked alkaline phosphatase (Sigma) was a mol.-wt standard. (ii) The running gel consisted of a linear 5-15\% acrylamide gradient; samples or a mixture of reference proteins $(4 \mu \mathrm{g}$ of each protein; Pharmacia) were applied to each lane after boiling in the presence of SDS containing mercaptoethanol; after electrophoresis, proteins were transferred to Immobilon membrane (Millipore Co., Bedford, MA, USA) by electrophoretic transfer ; ${ }^{33}$ the free hydrophobic sites on the membrane were blocked with Tween- $202 \%$ for $30 \mathrm{~min}$ and probed with HLfHRPO (diluted 1 in 200) for detecting the binding substance, in a Western blot; and mol.-wt standards in the gel were stained with Coomassie Brilliant Blue R.

\section{Results}

The binding of HLf to $S$. aureus strain MAS- 89 was maximal between $\mathrm{pH} 4.0$ and $9 \cdot 0$ (c. $9.8 \mathrm{fmol}$ bound). Treatment with unlabelled HLf elicited a dosedependent displacement of ${ }^{125} \mathrm{I}$-labelled HLf binding and required c. $0.8 \mu \mathrm{g}$ of unlabelled ligand for $50 \%$ inhibition (fig. 1). BLf blocked HLf binding, but other iron-binding proteins (transferrin and haemin) did not interfere in binding. Proteins that bind to distinct receptors on $S$. aureus such as immunoglobulin G, fibrinogen, fibronectin, collagen and laminin did not inhibit ${ }^{125} \mathrm{I}-\mathrm{HLf}$ binding (table). HLf binding reached $50 \%$ and $100 \%$ saturation within 10 and $90 \mathrm{~min}$ respectively (fig. 2 , inset). Scatchard plot analysis ${ }^{34}$ was non-linear and implied that there was a low $\left(1.55 \times 10^{7} \mathrm{~L} / \mathrm{mol}\right)$ and a high affinity $\left(2.70 \times 10^{8} \mathrm{~L} /\right.$ mol) binding mechanism. The average number of HLf-binding sites on strain MAS- 89 was estimated to be $5700 /$ cell (fig. 2).

\section{Nature of HLf-bacteria interaction}

The HLf binding to strain MAS-89 was abolished by heat treatment-partially $(<39 \%)$ at $80^{\circ} \mathrm{C}$ and

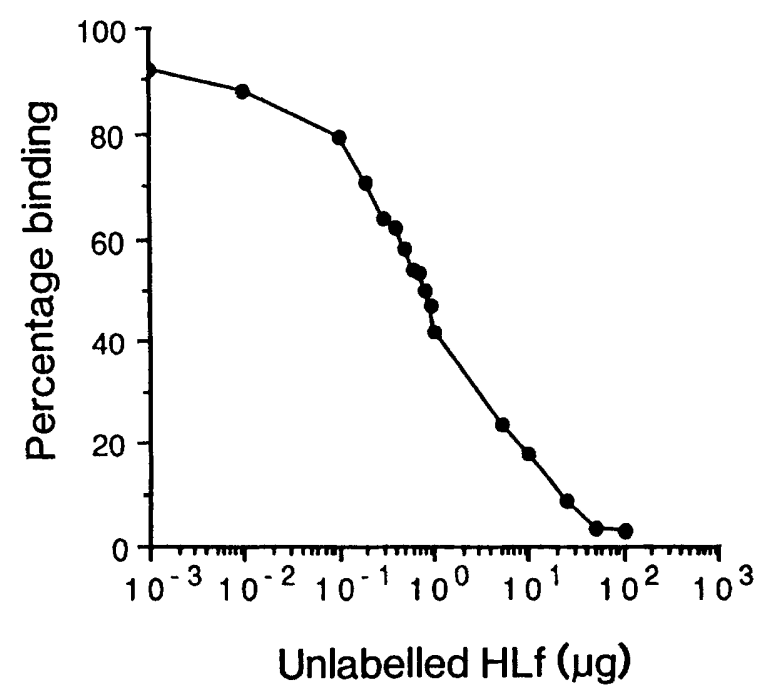

Fig. 1. Concentration-dependent displacement of ${ }^{125}$ I-labelled HLf binding to strain MAS- 89 with unlabelled ligand; $0.8 \mu \mathrm{g}$ of unlabelled HLf (added to $\sim 8 \mathrm{ng}$ of labelled HLf) caused $50 \%$ inhibition for $10^{9}$ cells. 
Table. Inhibitory effect of various unlabelled proteins on ${ }^{125} \mathrm{I}-\mathrm{HLf}$-binding to $S$. aureus strain MÁS-89

\begin{tabular}{lrr}
\hline \multirow{2}{*}{ Inhibitor } & $\begin{array}{r}\text { Mean (SD) percentage inhibition (mean } \pm \text { SD) at } \\
\text { a concentration of }\end{array}$ \\
\cline { 2 - 3 } & \multicolumn{1}{c}{$10 \mu \mathrm{g} / \mathrm{ml}$} & $100 \mu \mathrm{g} / \mathrm{ml}$ \\
\hline HLf & $77 \cdot 3(0 \cdot 7)$ & $80 \cdot 5(1 \cdot 1)$ \\
BLf & $84 \cdot 5(1 \cdot 1)$ & $87 \cdot 7(2 \cdot 3)$ \\
Transferrin (human) & $1 \cdot 8(1 \cdot 8)$ & $1 \cdot 1(2 \cdot 4)$ \\
Fibronectin (human) & $-5 \cdot 4(1 \cdot 6)$ & $0 \cdot 8(3 \cdot 6)$ \\
Fibrinogen (human) & $-5 \cdot 2(4 \cdot 1)$ & $6 \cdot 6(2 \cdot 7)$ \\
Immunoglobulin-G(human) & $-1 \cdot 3(2 \cdot 0)$ & $-16 \cdot 3(12 \cdot 3)$ \\
Laminin (murine) & $4 \cdot 1(4 \cdot 0)$ & Not tested \\
Collagen type-I (bovine) & $5 \cdot 0(2 \cdot 5)$ & $0 \cdot 6(2 \cdot 0)$ \\
Fetuin & $3 \cdot 7(0 \cdot 8)$ & $4 \cdot 6(0 \cdot 5)$ \\
Human serum albumin & $4 \cdot 4(0 \cdot 4)$ & $5 \cdot 1(3 \cdot 6)$ \\
& & \\
\hline
\end{tabular}

completely at $100^{\circ} \mathrm{C}$ after $1 \mathrm{~h}$. Treatment with proteinase $\mathrm{K}$ or trypsin reduced HLf binding by $50 \%$ and $45 \%$ respectively. A high concentration of pepsin reduced the binding by $25 \%$, but at a lower concentration, the HLf binding capacity was increased, due perhaps to the exposure of cryptic binding sites. Digestion with neuraminidase, $\alpha-1$ fucosidase, $\beta$ glucosidase or $\beta$-D-galactosidase did not change the HLf-binding ability. Oxidation of carbohydrate moieties on the staphylococcal cell surface by sodium periodate treatment did not change the HLf binding.

\section{Isolation of staphylococcal HLf-BP}

Strain MAS-89 cell lysate prepared by lysostaphin digestion contained c. $40 \mathrm{mg}$ of protein $/ \mathrm{ml}$. The possible interaction of $\operatorname{HLf}(\mathrm{pI} c .9 \cdot 0)$ with DNA or RNA was eliminated by hydrolysis with nucleases during extraction. A $27 \cdot 1-\mu 1$ volume of lysate (corre-

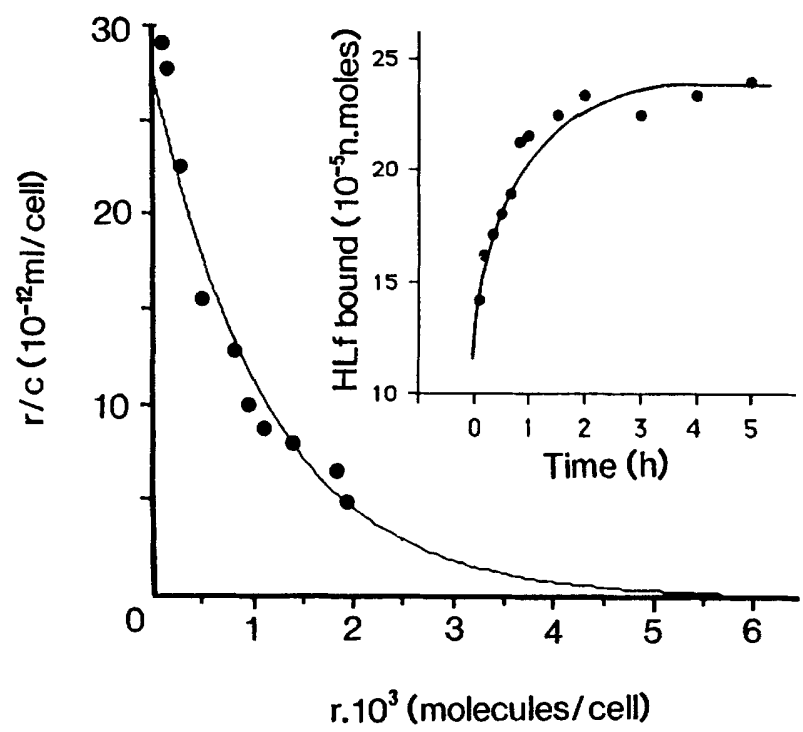

Fig. 2. Scatchard analysis ${ }^{34}$ of HLf-binding to strain MAS-89 $(1 \cdot 2 \times$ $\left.10^{10} \mathrm{cells} / \mathrm{ml}\right)$. An exponential curve $\left(\mathrm{y}=27486 \cdot 10^{(-00 \cdot 00038601 \times)}\right)$ was plotted and affinity constants $\left(\mathrm{K}_{\mathrm{a}}\right)$ of $2.70 \times 10^{8}$ and $1.55 \times$ $10^{7} \mathrm{~L} / \mathrm{mol}$ were obtained for high and low affinity binding respectively. The estimated number of binding sites was $c .5700 /$ cell. (Inset) Saturation of ${ }^{125} \mathrm{I}-\mathrm{HLf}$ binding as a function of time. sponding to $c .1 \cdot 1 \mathrm{mg}$ of protein) inhibited ${ }^{125} \mathrm{I}-\mathrm{HLf}$ binding to strain MAS- 89 whole cells by $50 \%$, indicating the presence of free and functional HLf-BP in the preparation (fig. 3). Lysate was fractionated by Q-Sepharose (fast flow) ion-exchange chromatography, and was eluted with a salt gradient $(0-1.0 \mathrm{M}$ $\mathrm{NaCl})$. The presence of HLf-BP in the fractions was detected by two methods: (i) by probing with HLfHRPO conjugate in an enzyme-linked ligand-binding assay, and (ii) by testing the blocking capacity in a ${ }^{125}$ I-HLf binding-inhibition assay. A peak eluted at $0.7 \mathrm{M}$ salt concentration showed HLf-binding and HLf-binding-inhibition activity (fig. 4a). Corresponding fractions were pooled and dialysed against distilled water. The isolated HLf-BP was found to be homogeneous in high-performance liquid chromatography with a Mono-Q column (fig. 4b). HLf-BP migrated as a single band of $\sim 450 \mathrm{Kda}$ in SDS-PAGE under nonreducing conditions (fig. 5A). The $450-\mathrm{Kda}$ material was recovered from the gel by electro-dialysis and the binding-blocking activity was reconfirmed. However,

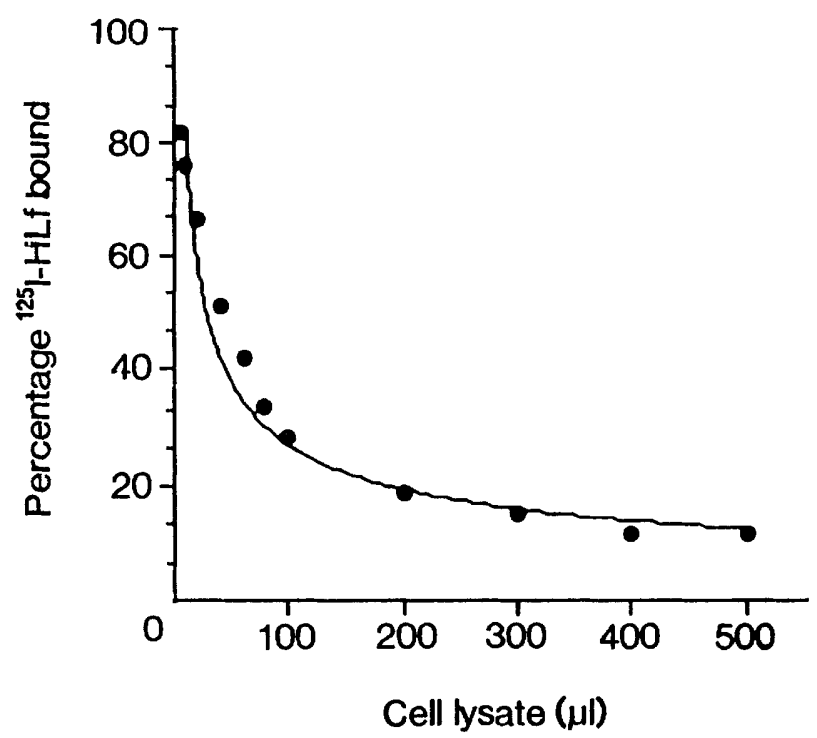

Fig. 3. Concentration-dependent HLf-binding inhibition activity of strain MAS-89 cell lysate. A logarithmic curve $(y=232790 \times$ -0.46638 ) was plotted. A volume of $27 \cdot 1 \mu \mathrm{l}$, corresponding to c. $1.1 \mathrm{mg}$ of protein, caused $50 \%$ inhibition. 
a

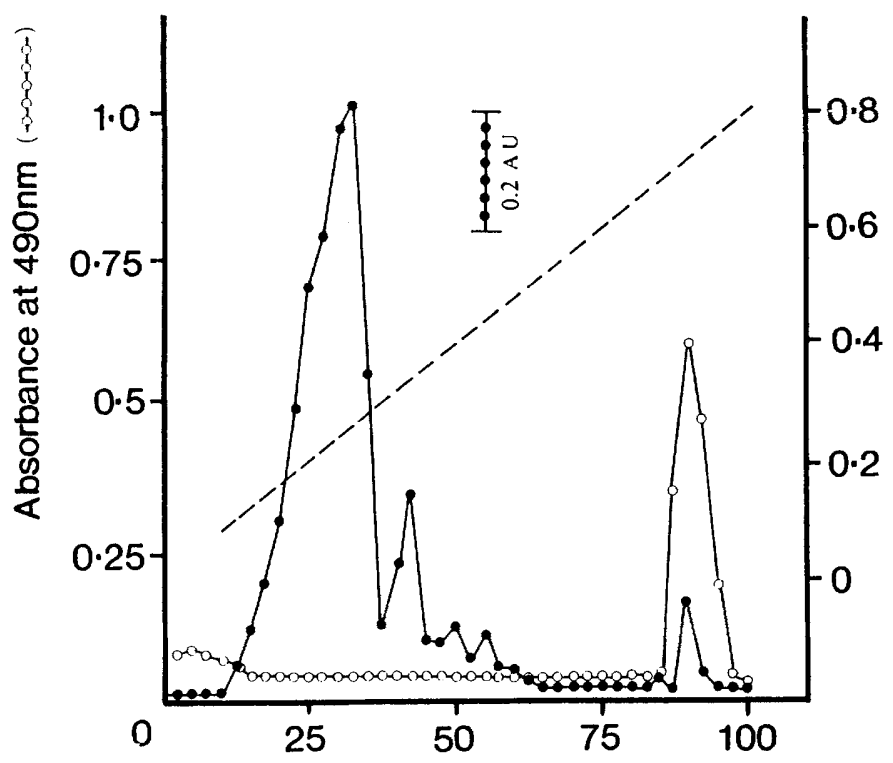

Fraction no. b

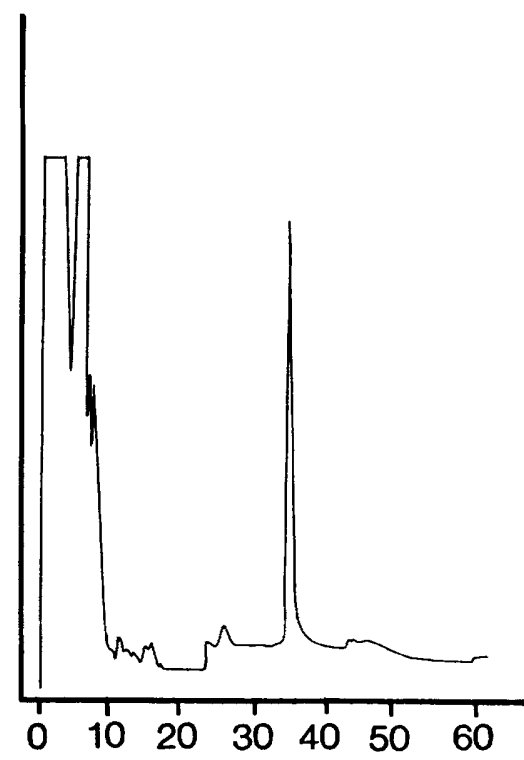

Retention time ( $\mathrm{min}$ )

Fig. 4. (a) HLf-binding activity in lysate fractions separated on Q-Sepharose and probed with HLf-peroxidase conjugate in an enzyme-linked ligand binding assay. (b) Analysis of HLf-BP activity-positive fractions (pooled and five-fold concentrated) for homogeneity by highperformance liquid chromatography on Mono-Q column. The major peak was at $\sim 0.9 \mathrm{M} \mathrm{NaCl}$ and appeared at $35 \mathrm{~min}$.

after reduction with $\beta$-mercaptoethanol, the HLf-BP resolved into two components of $c .62$ and c. $67 \mathrm{Kda}$ that reacted with HLf-HRPO; in the Western-blot analysis a similar pattern was obtained with the cell lysate (fig. 5B). Treatment with detergents (SDS, Triton, X-100, N-octyl- $\beta$-D-glycopyranoside, Tween20 , Novidet, Lubrol PX-all at $0.15 \%$ or $0.25 \%$ concentration) or with $6 \mathrm{M}$ urea did not dissociate the 450-K da substance. However, treatment with Tween$800.5 \%$ at $50^{\circ} \mathrm{C}$ for $2 \mathrm{~h}$ demonstrated moderate dissociation.

\section{Discussion}

Most staphylococcal infections originate at the skin or mucosal surface and one of the early host responses is generally acute inflammation. ${ }^{35}$ Various acutephase proteins, including $\mathrm{HLf}$, are secreted in large amounts by stimulated polymorphonuclear leucocytes during such an inflammatory process. ${ }^{2,36}$ HLf with iron-binding capacity may evoke physiological hyposideraemia in the inflammatory milieu, ${ }^{37}$ and elicit antimicrobial effects towards the invading pathogen. ${ }^{13,14}$ The antimicrobial action could be enhanced when HLf adsorbs to the bacterial surface. ${ }^{15,16}$ We have demonstrated recently the binding of HLf to various clinical isolates of $S$. aureus. ${ }^{22}$ Now we have examined further the nature of HLf-staphylococcal interaction and identified an HLf-BP in a previously well characterised clinical isolate of $S$. aureus, strain MAS89.

The HLf binding to strain MAS-89 could be saturated and was time-dependent, indicating that there was a limited number of binding sites on the cell surface. The ${ }^{125}$ I-HLf binding could be displaced by unlabelled protein, which showed that the interaction mechanism was reversible and indicated that both labelled and native ligands were recognised by the bacteria. The Scatchard-plot was non-linear and implied the presence of a low- and high-affinity HLfbinding mechanism. The binding affinity constants $\left(\mathrm{K}_{\mathrm{a}}\right.$ values) were within the range of affinity constants estimated for other staphylococcal receptors or for most antigen-antibody systems. ${ }^{38-41}$

Our in-vitro results indicated that the interaction of HLf with staphylococci occurs over a wide $\mathrm{pH}$ range

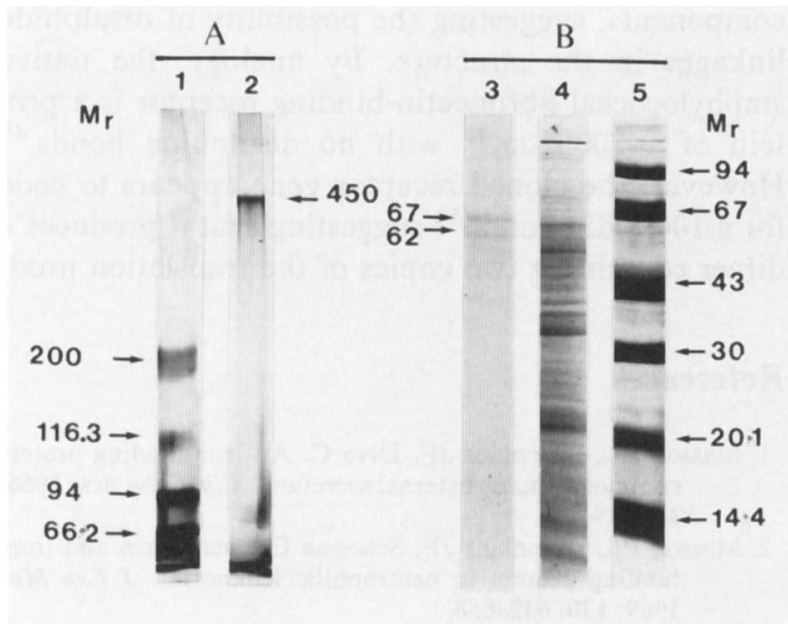

Fig. 5. Identification of HLf-BP in $S$. aureus strain MAS-89 by SDSPAGE. (A) Electrophoresis of non-reduced proteins on a $5 \%$ gel: lane 1 , high mol. wt standards (cross-linked alkaline phosphatase); 2, non-reduced HLf-BP (silver stained). (B) Electrophoresis of reduced proteins on a $5-15 \%$ gradient gel: Lane 3 , reduced HLfbinding component (Western blot with HLf-peroxidase conjugate); 4, strain MAS-89 cell lysate (Coomassie Brilliant Blue R, destained); 5 , low mol. wt standards. 
that includes the iso-electric point of HLf. Furthermore, $2 \mathrm{M} \mathrm{NaCl}$ did not dissociate the HLf-staphylococcal interaction (data not shown). Thus, the HLf binding did not seem to be electrostatic in nature and due to the basic charge of the protein. The HLf binding capacity at acidic $\mathrm{pH}$ may be of pathophysiological relevance in vivo, because the inflammatory milieu is acidic and is heavily infiltrated with Lfsecreting PMNLs. ${ }^{42}$

Unlabelled BLf displaced the ${ }^{125} \mathrm{I}-\mathrm{HLf}$ binding more effectively than the homologous ligand. Previously we demonstrated $67-$ and $92-\mathrm{Kda}$ BLf receptors in a $S$. aureus strain associated with bovine mastitis. ${ }^{24}$ Although HLf and BLf are both recognised, the interaction of BLf with staphylococci seems to be of a higher affinity. Amongst the veterinary clinical isolates of $S$. aureus and coagulase-negative staphylococci, the receptor density per cell was $2000-6000$, with affinity constants in the range $(0.96-11.9) \times 10^{6} \mathrm{~L} / \mathrm{mol}^{23,24}$

Specific receptors for $\mathrm{IgG}$, fibrinogen, fibronectin, collagen and laminin have been identified on $S$. aureus. ${ }^{43-47}$ These glycoproteins, or the iron-binding proteins transferrin and haemin, did not inhibit the binding, indicating that the HLf recognition process is distinct from previously described protein-staphylococcal interactions. The staphylococcal HLf-BP was partially destroyed by heat and of limited susceptibility to proteolytic digestion, suggesting partial involvement of a protein residue. Staphylococcal cell-surface receptors involved in binding of the plasma and subepithelial matrix components are also proteins. The N-terminal sequence and the total amino-acid composition of HLf-BP protein moiety was distinct from the previously known staphylococcal receptors (unpublished observations). Chromatographic and electrophoretic data suggested a tightly aggregated or a complexed HLf-BP, with a high $\mathrm{M}_{\mathrm{r}}$ of $\sim 450 \mathrm{Kda}$. When reduced, HLf-BP resolved into $62-$ and $67-\mathrm{Kda}$ components, suggesting the possibility of disulphide linkages in the structure. By analogy, the native staphylococcal fibronectin-binding receptor is a protein of $\sim 200 \mathrm{Kda},{ }^{48}$ with no disulphide bonds. ${ }^{49}$ However, the cloned receptor gene appears to code for a $100-\mathrm{Kda}$ protein ${ }^{50}$ suggesting that it produces a dimer containing two copies of the translation prod-

\section{References}

1. Masson PL, Heremans JF, Dive C. An iron-binding protein common to many external secretions. Clin Chim Acta 1966; 14: 735-739.

2. Masson PL, Heremans JF, Schonne E. Lactoferrin and ironbinding protein in neutrophilic leukocytes. $J$ Exp Med 1969; 130: 643-658.

3. Bennett RM, Kokocinski T. Lactoferrin turnover in man. Clin Sci $1979 ; 57: 453-460$.

4. Metz-Boutigue $\mathbf{M}-\mathrm{H}$, Jollès J, Mazurier J et al. Human lactotransferrin: amino acid sequence and structural comparisons with other transferrins. Eur J Biochem 1984; 145: $659-676$

5. Querinjean P, Masson PL, Heremans JF. Molecular weight, single-chain structure and amino acid composition of human lactoferrin. Eur J Biochem $1971 ; 20$ : 420-425. uct. ${ }^{38,51}$ Two serologically distinct fibronectin-binding mechanisms have been described recently in $S$. aureus $^{52}$ and molecular heterogeneity has also been reported in staphylococcal fibrinogen-binding protein. $^{53}$

Several mammalian receptors mediate glycoprotein clearance through recognition of different terminal carbohydrate units, in particular, $\mathrm{N}$-acetylglucosamine, mannose and fucose in the mononuclearphagocyte system. ${ }^{54}$ Of the two fucosyl residues in the HLf molecule, the one between the $\alpha-1-3$ linkage with $\mathrm{N}$-acetylglucosamine could be a potential binding determinant. ${ }^{45}$ In the present study, none of the glycosidases or carbohydrates (including fucose or mannose) inhibited HLf binding to $S$. aureus.

Identification of $\mathrm{HLf}$-binding receptors on bacteria and parasites opens a new dimension in the investigation of microbial pathogenesis. Peterson and Alderete $^{19}$ have described 75 - and 178 -Kda lowaffinity HLf-binding receptors (90 000 binding sites/ cell) on Trichomonas vaginalis. This interaction caused a 30-fold increase in the intracellular iron accumulation and enhanced the activity of pyruvate-ferrodoxin oxidoreductase (essential for energy metabolism) by six-fold in the trichomonads. Specific lactoferrin receptors have been demonstrated on $N$. gonorrhoeae $(101 \mathrm{Kda})$ and $N$. meningitidis $(105 \mathrm{Kda})^{18,20}$ but these pathogens do not seem to recognise BLf. Neisseriae can acquire iron from $\mathrm{HLf}^{55}$ and iron-limitation seems to enhance the HLf-binding capacity in these pathogens. Schryvers ${ }^{21}$ has demonstrated two HLf-binding proteins of 105 and $106 \mathrm{Kda}$ in $H$. influenzae. Specific HLf binding to $T$. pallidum, has also been reported. ${ }^{17}$ We have shown the binding of HLf to periodontitisassociated Prevotella intermedia, P. melaninogenica and Porphyromonas gingivalis. ${ }^{56}$

In conclusion, HLf has been shown to bind to specific cell-surface receptors of $S$. aureus. This novel receptor-ligand interaction is distinct from the staphylococcal receptors binding to plasma or connective tissue proteins described previously.

We thank Drs K-O. Eriksson, J. Erdei, D. Gerlach, S. Kalfas and $\mathrm{H}$. Burling for stimulating discussions, and the Greta/Johan Kocks Foundation, the Alfred Osterlunds Foundation, and the Faculty of Medicine, University of Lund, for financial support.

6. Harris WR. Thermodynamics of gallium complexation by human lactoferrin. Biochemistry $1986 ; 25$ : 803-808.

7. Masson PL, Heremans JF. Metal-combining properties of human lactoferrin (red milk protein). I. The involvement of bicarbonate in the reaction. Eur J Biochem 1968; 6: 579 584.

8. Birgens HS. The biological significance of lactoferrin in haematology. Scand J Haematol 1984; 33: 225-230.

9. Broxmeyer HE, Smithyman A, Eger RR, Meyers PA, De Sousa $M$. Identification of lactoferrin as the granulocyte-derived inhibitor of colony-stimulating activity production. $J$ Exp Med 1978; 148 : 1052-1067.

10. Broxmeyer HE, Platzer E. Lactoferrin acts on I-A and I-E/C antigen $^{+}$subpopulations of mouse peritoneal macrophages in the absence of $T$ lymphocytes and other cell types to inhibit production of granulocyte-macrophage colony stimulatory factors in vitro. $J$ Immunol $1984 ; 133$ : 306-314. 
11. Ambruso DR, Johnston RB. Lactoferrin enhances hydroxyl radical production by human neutrophils, neutrophil particulate fractions, and an enzymatic generating system. $J$ Clin Invest 1981; 67: 352-360.

12. Bullen JJ, Armstrong JA. The role of lactoferrin in the bactericidal function of polymorphonuclear leucocytes. Immunology 1979; 36: 781-791.

13. Arnold RR, Cole MF, McGhee JR. A bactericidal effect for human lactoferrin. Science 1977; 197: 263-265.

14. Oram JD, Reiter B. Inhibition of bacteria by lactoferrin and other iron-chelating agents. Biochim Biophys Acta 1968; 170: $351-365$.

15. Dalmastri C, Valenti $P$, Visca $P$, Vittorioso P, Orsi N. Enhanced antimicrobial activity of lactoferrin by binding to the bacterial surface. Microbiologica $1988 ; 11$ : 225-230.

16. Ellison RT, Theodore GJ, LaForce FM. Damage to outer membrane of enteric gram-negative bacteria by lactoferrin and transferrin. Infect Immun 1988; 56: 2774-2781.

17. Alderete JF, Peterson KM, Baseman JB. Affinities of Treponema pallidum for human lactoferrin and transferrin. Genitourin Med 1988; 64: 359-363.

18. Lee BC, Schryvers AB. Specificity of the lactoferrin and transferrin receptors in Neisseria gonorrhoeae. Mol Microbiol 1988; 2: 827-829.

19. Peterson KM, Alderete JF. Iron uptake and increased intracellular enzyme activity follow host lactoferrin binding by Trichomonas vaginalis receptors. J Exp Med 1984; 160: 398-410.

20. Schryvers AB, Morris LJ. Identification and characterization of the human lactoferrin-binding protein from Neisseria meningitidis. Infect Immun 1988; 56: 1144-1149.

21. Schryvers AB. Identification of the transferrin- and lactoferrinbinding proteins in Haemophilus influenzae.J Med Microbiol 1989; 29: 121-130.

22. Naidu AS, Miedzobrodzki J, Musser JM, Rosdahl VT, Hedström SȦ, Forsgren A. Human lactoferrin binding in clinical isolates of Staphylococcus aureus. J Med Microbiol 1991 ; 34: 323-328.

23. Naidu AS, Miedzobrodzki J, Andersson M, Nilsson L-E, Forsgren A, Watts JL. Bovine lactoferrin binding to six species of coagulase-negative staphylococci isolated from bovine intramammary infections. J Clin Microbiol 1990; 28: 2312-2319.

24. Naidu AS, Andersson M, Miedzobrodzki J, Forsgren A, Watts JL. Bovine lactoferrin receptors in Staphylococcus aureus isolated from bovine mastitis. J Dairy Sci 1991; 74: 12181226.

25. Veunto M, Vaheri A. Purification of fibronectin from human plasma by affinity chromatography under non-denaturing conditions. Biochem J 1979; 183: 331-337.

26. Naidu AS, Kamme C, Ljungh A, Wadström T. Levels of toxic shock syndrome toxin-1 production among Staphylococcus aureus strains and clinical implications. Z Bl Bakt Hyg A 1989; 270 : 337-344.

27. Naidu AS, Jimenez J, Rollof J et al. Crystal violet binding, cell surface properties and extracellular enzyme profiles of Staphylococcus aureus producing toxic shock syndrome toxin-1. Int J Med Microbiol 1989; 271: 11-21.

28. Naidu AS, Ekstrand J, Wadström T. Binding of Type I and Type II collagens to Staphylococcus aureus strains isolated from patients with toxic shock syndrome compared to other staphylococcal infections. FEMS Microbiol Immunol $1989 ; 1: 219-227$.

29. Rydén C, Rubin K, Speziale P, Höök M, Lindberg M, Wadström T. Fibronectin receptors from Staphylococcus aureus. J Biol Chem 1983; 258: 3396-3401.

30. Nakamura RM, Voller A, Bidwell DE. Enzyme immunoassays: heterogeneous and homogeneous systems. In: Weir DM (ed) Handbook of experimental immunology. Oxford, Blackwell Scientific Publications. 1986: 27.1-27.20.

31. Engvall E, Perlmann P. Enzyme-linked immunosorbent assay (ELISA). Quantitative assay of immunoglobulin G. Immunochemistry $1971 ; 8: 71-874$.

32. Studier FW. Analysis of bacteriophage T7 early RNAs and proteins on slab gels. J Mol Biol 1973; 79: 237-248.

33. Towbin H, Staechelin T, Gordon J. Electrophoretic transfer of proteins from polyacrylamide gels to nitrocellulose sheets: procedure and some applications. Proc Natl Acad Sci USA $1979 ; 76: 4350-4354$.
34. Scatchard G. The attractions of proteins for small molecules and ions. Ann NY Acad Sci 1949; 51 : 660-672.

35. Sheagren JN. Staphylococcus aureus: the persistent pathogen. $N$ Engl J Med 1984; 310: 1368-1373.

36. Lerche A, Bisgaard H, Christensen JD, Venge P, Dahl R, Søndergaard J. Lactoferrin, myeloperoxidase, lysozyme and eosinophil cationic protein in exudate in delayed type hypersensitivity. Allergy 1988; 43: 139-145.

37. van Snick JL, Masson PL, Heremans JF. The involvement of lactoferrin in the hyposideremia of acute inflammation. $J$ Exp Med 1974; 140: 1068-1084.

38. Höök M, Switalski LM, Wadström T, Lindberg M. Interactions of pathogenic microorganisms with fibronectin. In: Mosher DF (ed) Fibronectin. New York, Academic Press. 1989: 295-308.

39. Kronvall G, Quie PG, Williams RC. Quantitation of staphylococcal protein $\mathrm{A}$ : determination of equilibrium constant and number of protein A residues on bacteria. $J$ Immunol $1970 ; 104: 273-278$.

40. Switzlski LM, Speziale P, Höök M. Isolation and characterization of a putative collagen receptor from Staphylococcus aureus strain Cowan 1. J Biol Chem 1989; 264: 2108021086.

41. Kronvall G, Seal US, Finstad J, Williams RC. Phylogenetic insight into evolution of mammalian Fc fragment of $\gamma \mathrm{G}-$ globulin using staphylococcal protein A. J Immunol 1970; 104: 140-147.

42. Lehrer RI, Ganz T, Selsted ME, Babior BM, Curnutte JT. Neutrophils and host defense. Ann Intern Med 1988; 109: $127-142$.

43. Forsgren A, Sjöquist J. "Protein A" from S. aureus. I. Pseudoimmune reaction with human $\gamma$-globulin. $J$ Immunol 1966; 97: 822-827.

44. Kuusela P. Fibronectin binds to Staphylococcus aureus. Nature 1978; 276: 718-720.

45. Fuquay JI, Loo DT, Barnes DW. Binding of Staphylococcus aureus by human serum spreading factor in an in-vitro assay. Infect Immun 1986; 52: 714-717.

46. Lopes JD, dos Reis M, Brentani RR. Presence of laminin receptors in Staphylococcus aureus. Science 1985; 229 : 275277.

47. Carret G, Emonard H, Fardel G, Druguet M, Herbage D, Flandrois JP. Gelatin and collagen binding to Staphylococcus aureus strains. Ann Inst Pasteur Microbiol 1985; 136A: 241-245.

48. Espersen F, Clemmensen I. Isolation of a fibronectin-binding protein from Staphylococcus aureus. Infect Immun 1982; 37: 526-531.

49. Fröman G, Switalski LM, Speziale $P$, Höök $M$. Isolation and characterization of a fibronectin receptor from Staphylococcus aureus. J Biol Chem 1987; 262: 6564-6571.

50. Uhlén M, Guss B, Nilsson B, Gatenbeck S, Philipson L, Lindberg $\mathbf{M}$. Complete sequence of the staphylococcal gene encoding protein $A$. A gene evolved through multiple duplications. J Biol Chem 1984; 259: 1695-1702.

51. Signäs C, Raucci G, Jönsson K et al. Nucleotide sequence of the gene for a fibronectin-binding protein from Staphylococcus aureus. Use of this peptide sequence in the synthesis of biologically active peptides. Proc Natl Acad Sci USA 1989; 86: 699-703.

52. Naidu AS, Schalén C, Flock J-I, Nilsson I, Miedzobrodzki J, Wadström T. Serological difference in the fibronectin binding to protein-A deficient mutants of Staphylococcus aureus. In: Wadström T, Eliasson I, Holder I, Ljungh A, (eds) Pathogenesis of wound and biomaterial-associated infections. London, Springer-Verlag. 1990: 353-360.

53. Usui $Y$. Biochemical properties of fibrinogen binding protein (clumping factor) of the staphylococcal cell surface. $\mathrm{Zbl}$ Bakt Hyg A 1986; 262: 287-297.

54. Imber MJ, Pizzo SV. Clearance and binding of native and defucosylated lactoferrin. Biochem $J$ 1983; 212: 249-257.

55. Mickelson PA, Blackman E, Sparling PF. Ability of Neisseria gonorrhoeae, Nesseria meningitidis, and commensal Neisseria species to obtain iron from lactoferrin. Infect Immun 1982; 35: 915-920.

56. Kalfas S, Andersson M, Edwardsson S, Forsgren A, Naidu AS. Human lactoferrin binding to Porphyromonas gingivalis, Prevotella intermedia and Prevotella melaninogenica. Oral Microbiol Immunol $1991 ; 6$ : in press. 